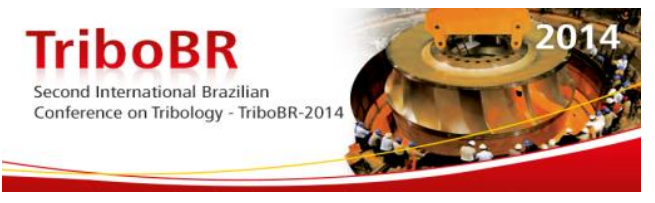

\title{
KINETIC FRICTION MODELING AND STANDARD UNCERTAINTY MEASUREMENT DETERMINATION FOR SLIDING BEARING ON SHAFT APPARATUS*
}

João Luiz do Vale

Carlos Henrique da Silva ${ }^{2}$

\begin{abstract}
In standard wear tests, such as pin on disk (ASTM-G99) or block on ring (ASTMG77), the apparatus simulates conditions that are often different from a machine element real application. Therefore, for an accurate investigation of a tribological application, it is essential to test the real condition in which there are similarities as: geometry, contact details, force application mode, materials, among others. It emphasizes that for studies involving polymeric materials it becomes extremely relevant. Thus, the Laboratory of Surfaces and Contact (LASC) at UTFPR developed an apparatus for sliding bearing on shaft test. In that equipment, loads are applied by a dead-weight system and the frictional force is measured on a load cell. The apparatus operating ranges for load added to the dead weight system and rotation shaft are from 0.2 to $5.0 \mathrm{kgf}$ and from 260 to $3500 \mathrm{rpm}$, respectively. This paper presents a detailed evaluation of such apparatus, which includes free-body diagrams analysis and a deduction to obtain an equation for the kinetic friction coefficient. Also, the standard measurement uncertainties of a caliper, an electronic scale, and a cell load were determined. It was verified that the kinetic friction coefficient equation is dependent on the apparatus geometry, the applied load, and the frictional force value. Additionally, through the statistical significance analysis it was concluded that some terms in the equation were not significant. Finally, through the application of the error propagation theory in the kinetic friction coefficient equation, the standard measurement uncertainty of the apparatus which showed a value nearby 0.002 along the operating range of the apparatus was obtained.
\end{abstract}

Keywords: Sliding bearing; Standard uncertainty; Tribological test; Error propagation; PTFE.

1 Mechanical Engineering Department, Federal University of Technology - Paraná (UTFPR), Campus Londrina, Londrina, PR, Brazil.joaovale@utfpr@edu.br

2 Surfaces and Contact Lab. (LASC), Federal University of Technology - Paraná (UTFPR), Campus Curitiba, Curitiba, PR, Brazil.

* Technical contribution to the $2^{\text {nd }}$ International Brazilian Conference on Tribology - TriboBR 2014,November $3^{\text {rd }}$ to $5^{\text {th }}, 2014$, Foz do Iguaçu, PR, Brazil. 


\section{INTRODUCTION}

There are many researches in literature that are conducted to develop materials for tribological applications. Similarly, efforts are made for characterization and investigation of behaviors demonstrated [1-5].

However, the behavior of materials in a tribological application is complex and depends on the nature and the morphology of material and components added in its composition [1]. Also, the performance is influenced by the surface finish and the contact conditions [6]. Hence, experimental tests are essential for a complete understanding of a specific tribosystem [7]. This information shall be provided to ensure theoretical basis for selection of materials, especially for high-performance tribological applications which are demanded, commonly, in new technologies [8].

There are many standard tribological tests, such as pin on disk (ASTM-G99) or block on ring (ASTM-G77). However, the apparatus simulates conditions that are often different from a machine element real application. Nevertheless, for an accurate investigation of a tribological application, it is essential to test the real condition in which there are similarities, as: geometry, contact details, force application mode, materials, among others. It emphasizes that for studies involving polymeric materials it becomes extremely relevant [9].

This article presents a sliding bearing on shaft apparatus, which was developed and built at the UTFPR's Surfaces and Contact Laboratory (LASC). This apparatus simulates a condition very close to the real application of sliding bearings. Several papers can be found, in which tests with similar design apparatus were carried out. Researchers commonly conduct studies of the friction coefficient behavior in lubricated systems, with Stribeck curves evaluation [10-13]. Also, discussions about wear in non-lubricated system can be found [14,15]. Ünlü and Atik [16] present a friction coefficient modeling, by free body diagram analysis, and effects of friction bearings have been examined at dry and lubricated conditions. Nevertheless, measurement uncertainty studies were not presented.

The main objective of this work is to evaluate the apparatus and deduce an equation to determine the kinetic friction coefficient. It also includes an analysis of errors and the determination of the apparatus standard uncertainty.

\section{MATERIALS AND METHODS}

\subsection{Apparatus and Measuring Instruments}

The apparatus under study can be seen in Figure 1. In general lines, the tribometer has a shaft, supported by bearing supports, which is coupled to an electric drive motor, whose speed control is done by a frequency converter. At the shaft end, the counterbody is fixed with a screw and a washer. The specimen is coupled and forced against the counterbody with a normal force applied by a ball bearing which is assembled in the rod load. The weights, in a total of four, are added to the rod load and provide the normal force through a deadweight system. The specimen transmits, through the specimen's screw, the kinetic friction force which is generated at the interface to the load transmission rod. Finally, the value is measured on the load cell. The operating range of the apparatus is shown in Table 1.

* Technical contribution to the $2^{\text {nd }}$ International Brazilian Conference on Tribology - TriboBR 2014,November3'd to $5^{\text {th }}, 2014$, Foz do Iguaçu, PR, Brazil. 


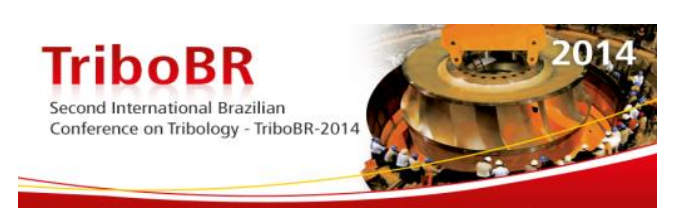

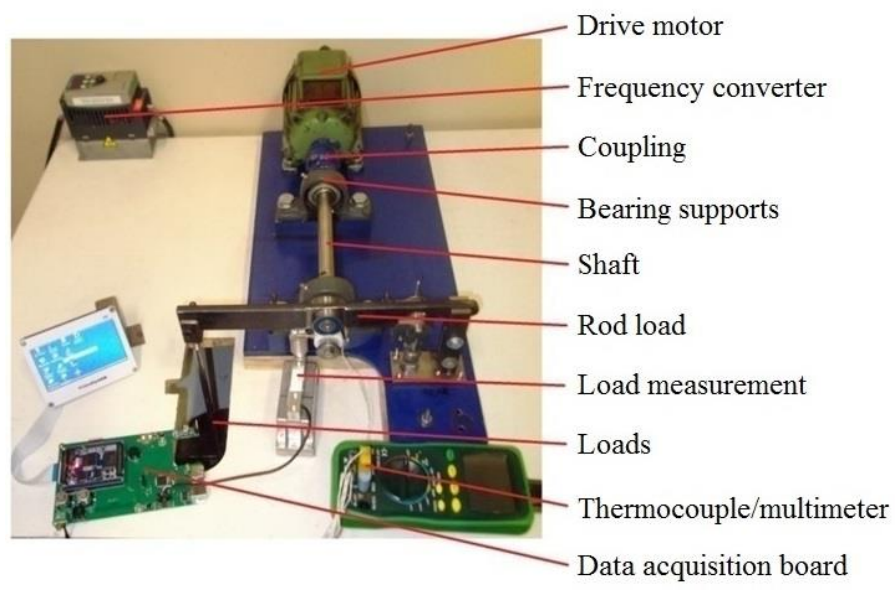

(a)

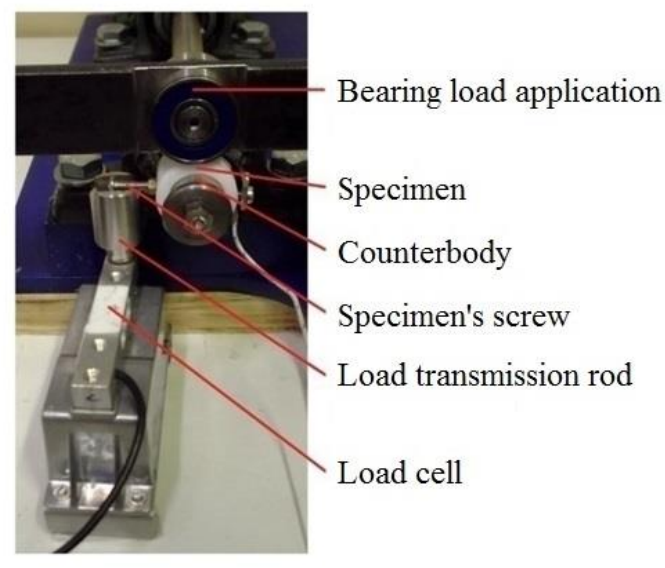

(b)

Figure 1. Kinetic friction machine for plain bearing on shaft test: (a) Overview (b) Measurement system detail.

Table 1. Operating range of the apparatus.

\begin{tabular}{cc}
\hline Parameter & Range \\
\hline Weight added to the rod load [gf] & $200-5000$ \\
Rotation shaft $(\mathrm{n})[\mathrm{rpm}]$ & $260-3500$ \\
\hline
\end{tabular}

During the tests, the temperature on contact and the force transmitted to the load cell were automatically collected. The acquisition rate applied was 12 values per minute. The thermocouple used was K-type, chromel-alumel junction, with operating range from $-40^{\circ} \mathrm{C}$ to $204^{\circ} \mathrm{C}$ and $\pm 2.2^{\circ} \mathrm{C}$ of measurement uncertainty. The hot joint of the thermocouple was inserted in the specimen bulk at a distance of $0.5 \mathrm{~mm}$ far from the contact surface, following the recommendations of the ASM Handbook [17]. In the tests, after the thermocouple assembled the hole was filled up with thermal grease in order to increase conductivity. The multimeter used has data output RS-232.

The load measurement system counted on a load cell with resistive strain gage, with a $2 \mathrm{~kg}$ capacity and a $0.1 \mathrm{~g}$ resolution. The load cell was connected to a data acquisition board, which is based on an ARM structure with the following specifications: ARM $6410533 \mathrm{MHz}, 256 \mathrm{MB}$ of RAM and $2 \mathrm{~GB}$ flash memory. Data was recorded on a flash drive which was connected to the USB port. The logical data acquisition is collecting 100 values, filtering, and putting in a buffer of nine positions, which presents the average of these nine values on the screen. Every update discards the oldest value in the buffer and makes a new measurement. That process is named moving average, and thus can provide a more stable and accurate value. The calibration of the system was made with standard weight $200 \pm 0.05 \mathrm{~g}$.

In order to obtain an equation for the kinetic friction coefficient was adopted the $\mathrm{Da}$ Vince friction coefficient model [18] and a free-body diagrams analysis, for a static condition, was conducted.

The measurements mass was determined by using an electronic precision scale, whose operating range is $0-2200 \mathrm{~g}$ and its accuracy is $0.01 \mathrm{~g}$. The instrument used to measure the length was a vernier caliper whose accuracy is $0.05 \mathrm{~mm}$.

\subsection{Statistical Analysis}

In this paper, instruments measurement uncertainties are indicated by standard uncertainty, which is the most common way to represent measurement uncertainty in

\footnotetext{
* Technical contribution to the $2^{\text {nd }}$ International Brazilian Conference on Tribology - TriboBR 2014,November $3^{\text {rd }}$ to $5^{\text {th }}, 2014$, Foz do Iguaçu, PR, Brazil.
} 


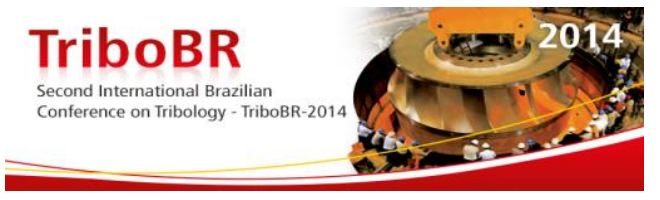

experimental results [19]. In such cases, it can be represented by a standard deviation, which might also be called standard error [20]. The measurement uncertainty, intrinsic to a particular instrument is associated with statistical and systematic errors. The first types of errors are distributed randomly around the measure true value. The systematic errors, in its turn, lead to a difference of a constant amount between a measure and its true value. In order to determine an instrument standard uncertainty, $\sigma$, the Equation (1) can be applied [19].

$\sigma^{2}=\sigma_{e}^{2}+\sigma_{s}^{2}$

where:

$\sigma_{e}:$ Standard uncertainty associated with statistical errors;

$\sigma_{s}:$ Standard uncertainty associated with systematic errors.

When there are several systematic errors, the corresponding uncertainties can be obtained individually and combined by Equation (2).

$\sigma_{\mathrm{s}}^{2}=\sum_{\mathrm{i}=1}^{\mathrm{n}} \sigma_{\mathrm{s}_{\mathrm{n}}}^{2}$

A standard uncertainty can be determined with the instrument error limit, $E$, with a confidence level of $95.45 \%$, by Equation (3). This Equation is valid for both systematic and statistical errors. However, distributions of errors must be normal [19].

$\sigma=\frac{1}{2} \mathrm{E}$

For systematic calibration errors is common to consider the instrument accuracy as the error limit, and to assume that the error distribution is normal. In the case of digital instruments, the last digit fluctuation must be observed. Thus, the statistical error limit, $E_{e}$, is considered as the difference between the mean and the maximum measured value, according to Equation (4).

$\mathrm{E}_{\mathrm{e}}=\overline{\mathrm{z}}-\mathrm{z}_{\max }$

where:

$\bar{z}: \quad$ Mean value of a generic measurement using a digital instrument;

$z_{\text {max }}$ : Maximum value of a generic measurement using a digital instrument.

In cases in which a quantity is calculated by using other values, an analysis of error propagation must be made. For that purpose, a generic quantity $j$ is considered and calculated based on quantities: $r, s$ and $t$, and their standard uncertainties, independent of each other, $\sigma_{r}, \sigma_{s}$ and $\sigma_{t}$. Thus, it is possible to calculate the standard uncertainty of the quantity $j, \sigma_{j}$, with Equation (5) [19].

$\sigma_{j}^{2}=\left(\frac{\partial j}{\partial r}\right)^{2} \sigma_{r}^{2}+\left(\frac{\partial j}{\partial s}\right)^{2} \sigma_{s}^{2}+\left(\frac{\partial j}{\partial t}\right)^{2} \sigma_{t}^{2}+\cdots$

In this paper, the Shapiro-Wilk [21] test was chosen to verify whether a sample came from a normally distributed population. This is an inference test and its nullhypothesis is that the population is normally distributed. A significance level of 0.05 was adopted. According to the test, if the $\mathrm{W}$-value calculated with a sample data is greater than a statistical critic value of Shapiro-Wilk test, then the null hypothesis that the data came from a normally distributed population cannot be rejected.

* Technical contribution to the $2^{\text {nd }}$ International Brazilian Conference on Tribology - TriboBR 2014,November3 ${ }^{\text {rd }}$ to $5^{\text {th }}, 2014$, Foz do Iguaçu, PR, Brazil. 


\section{RESULTS AND DISCUSSION}

\subsection{Kinetic Friction Coefficient Model}

The first step for the evaluation of the apparatus developed was to conduct a strict analysis of the forces involved by the free-body diagrams evaluation. This is fundamental to deduce an equation needed to determine the kinetic friction coefficient for the apparatus in study. The kinetic friction coefficient, $\mu$, for the proposed case, was calculated according to Equation (6) as the ratio between the friction force, $F_{f}$, and the applied normal force, $F_{N}$.

$\mu=\frac{F_{f}}{F_{N}}$

Initially, it considers the free-body diagram of the rod load as shown in Figure 2. The system is in equilibrium and it is possible to identify the pivot point "O".

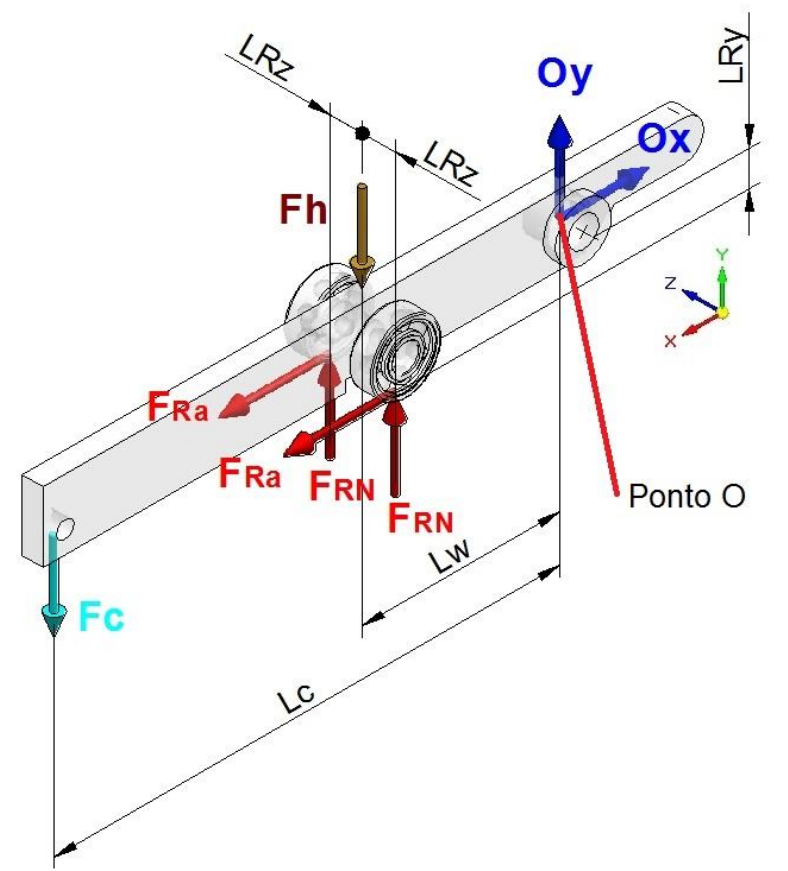

Figure 2. The rod load free-body diagram.

Where:

$F_{h}$ : Rod load's weight force considered at the point of the normal load application [N];

$F_{w}$ : Weights added to the rod load [N];

$F_{R a}$ : Frictional force generated by the tendency of bearing rotation [N];

$F_{R N}$ : Counterbody's normal reaction [N];

$L_{w}$ : Distance from the center of rotation to the point of normal load application [mm];

$L_{R x}:$ Distance from the pivot to the point of the normal load application [mm];

$L_{R y}:$ Distance from the pivot to the bearing-counterbody contact [mm];

$L_{R z}$ : Distance from the load rod's center to the bearing's center [mm];

$O_{x}$ : Reaction force at the pivot point on the $x$ axis $[\mathrm{N}]$;

$O_{y}:$ Reaction force at the pivot point on the $y$ axis $[\mathrm{N}]$.

* Technical contribution to the $2^{\text {nd }}$ International Brazilian Conference on Tribology - TriboBR 2014,November3 ${ }^{\text {rd }}$ to $5^{\text {th }}, 2014$, Foz do Iguaçu, PR, Brazil. 
Due to the symmetry on the XY plane it was considered that the forces, $F_{R N}$ and $F_{R a}$, are equal in each bearing. Now, applying the sum of moments about the $z$ axis, at pivot point "O", has the Equation (7).

$-\mathrm{F}_{\mathrm{w}} \mathrm{L}_{\mathrm{w}}-\mathrm{F}_{\mathrm{h}} \mathrm{L}_{\mathrm{Rx}}+2 \mathrm{~F}_{\mathrm{RN}} \mathrm{L}_{\mathrm{Rx}}+2 \mathrm{~F}_{\mathrm{Ra}} \mathrm{L}_{\mathrm{Ry}}=0$

It is necessary to analyze the forces in the bearing to determine the value of $F_{R a}$. For that purpose, Figure 3 (a) presents the bearing free-body diagram. Thus, it can be noted the frictional torque of the bearing, $M_{R}[\mathrm{Nm}]$, which according SKF [22] is the total friction resistance to the rolling movement associated with the rotating parts, the cage and the lubricant.

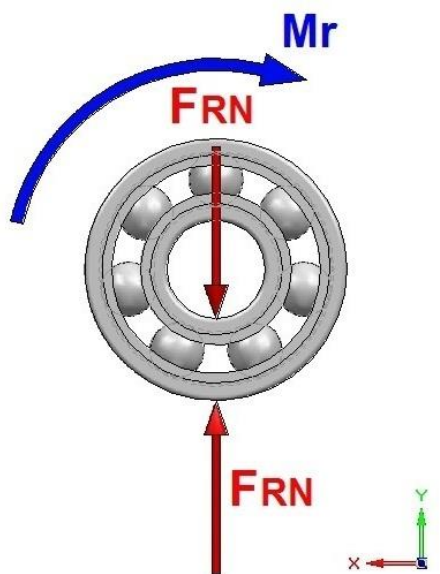

(a)

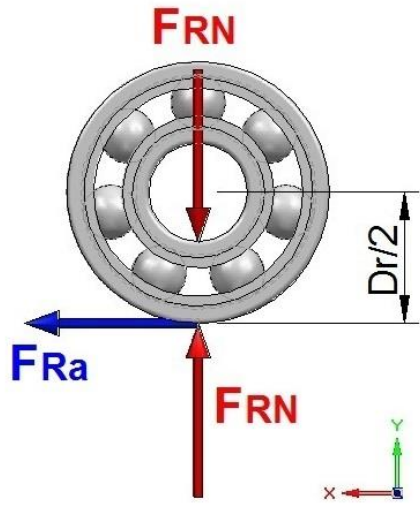

(b)

Figure 3. The bearing free-body diagram: (a) the frictional torque of the bearing (b) the bearing friction force $F_{R a}$ and the distance $D_{R} / 2$.

The frictional torque of the bearing, as shown in Figure 3 (a), is equivalent to the frictional force of the bearing, $F_{R a}[\mathrm{~N}]$, applied at a distance $D_{R} / 2$, in this case, which is presented in Figure 3 (b). Thus, it can present the Equation (8).

$M_{R}=F_{R a} \frac{D_{R}}{2}$

The frictional torque of the bearing can be estimated with good precision by Equation (9). But, it is necessary that the value of the radial bearing load remains close to $10 \%$ of its maximum dynamic load, $\mathrm{C}[\mathrm{N}]$, and in normal operation and lubrication conditions [22].

$M_{R}=0.5 \mu_{R} F_{R N} d_{R}$

Where:

$\mu_{R}:$ Kinetic friction coefficient of the bearing [-];

$d_{R}$ : Inner diameter of the bearing [mm];

$D_{R}$ : Bearing outside diameter [mm].

For the ball bearing used in the apparatus, 6201-2RS, it has $\mathrm{C}=6890 \mathrm{~N}, \mu_{R}=0.0015$, $d_{R}=12 \mathrm{~mm}$ and $D_{R}=32 \mathrm{~mm}$ [22]. Thus, it can use the model proposed, because $F_{R N}$ $<0.1 \mathrm{C}$, as can be seen in the operating range of the apparatus, in. Table 1. Substituting Equation (9) into Equation (8) and evidencing the frictional force of the bearing, Equation (10) can be obtained, showing that this is an exclusive function of the counterbody's normal reaction.

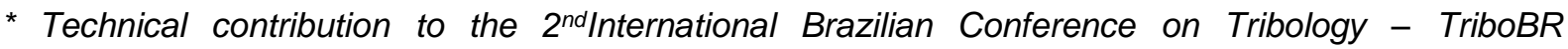
2014,November $3^{\text {rd }}$ to $5^{\text {th }}, 2014$, Foz do Iguaçu, PR, Brazil. 
$F_{R a} f\left(F_{R N}\right)=F_{R N} \mu_{R} \frac{d_{R}}{D_{R}}$

Now, substituting Equation (10) in Equation (7) and solving to $F_{R N}$, Equation (11) is deduced, which shows only dependency of weights added to the rod load and constants associated with the apparatus geometry.

$F_{R N}=f\left(F_{w}\right)=\frac{F_{w} L_{w}+F_{h} L_{R x}}{2\left(L_{R x}+\mu_{R} \frac{d_{R}}{D_{R}} L_{R y}\right)}$

Figure 4 shows the specimen free-body diagram. The $F_{R N}$ and $F_{R a}$ forces are applied by the bearings, as seen in Figure 3 . Due to the counterbody removal, the contact force, $F_{N}[N]$, was added, and the frictional force, $F_{f}[N]$, generated by the rotation of the counter body. Each weight force was positioned in the mass center of the body.

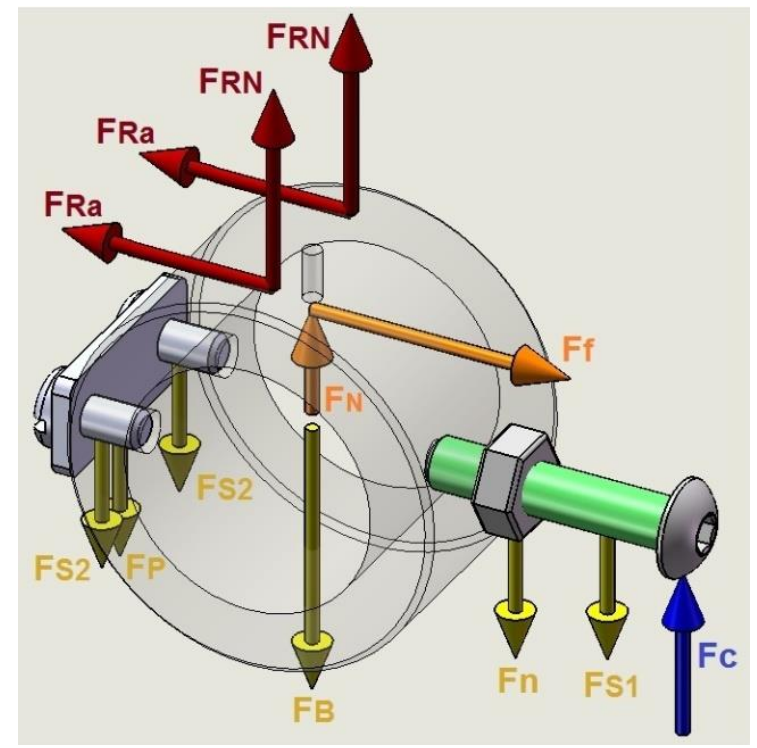

(a)

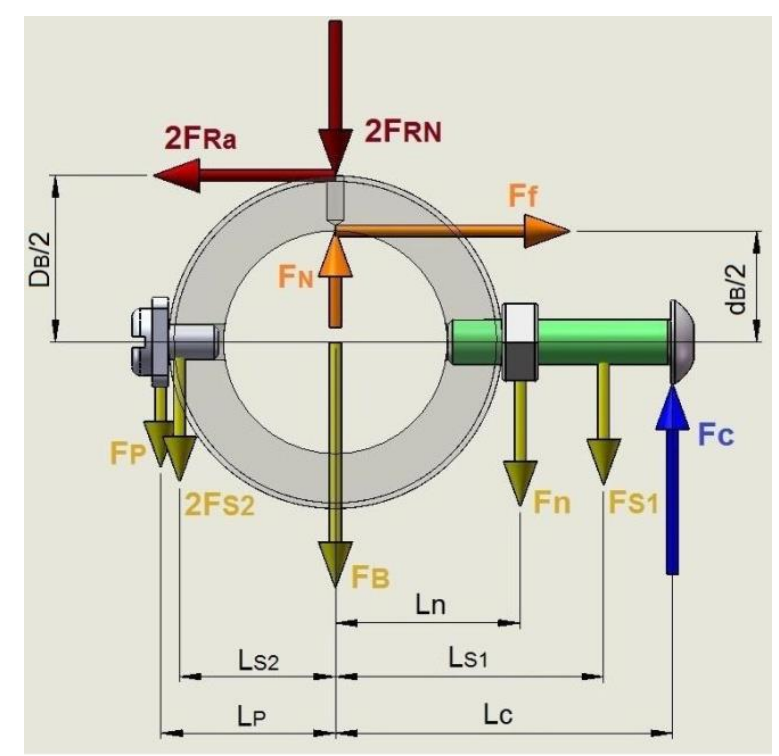

(b)

Where:

Figure 4. The specimen free-body diagram: (a) isometric view (b) plan view "xy".

$F_{B}:$ Specimen weight $[\mathrm{N}]$;

$F_{C}$ : Measurement in the load cell $[\mathrm{N}]$;

$F_{S 1}$ : Weight of screw one $[\mathrm{N}]$;

$F_{s 2}$ : Weight of screw two [N];

$F_{n}: \quad$ Nut weight $[\mathrm{N}]$

$F_{p}$ : Plate weight [N].

Equation (12) is obtained by applying the sum of forces in the y-axis.

$-2 F_{R N}+F_{N}-F_{B}-F_{S 1}-2 F_{S 2}-F_{n}-F_{P}+F_{C}=0$

The next step is to determine the Equation (13) by substituting Equation (11) in Equation (12) and solving for $F_{N}$.

$F_{N}=f\left(F_{w}\right)=\frac{F_{w} L_{w}+F_{h} L_{R x}}{L_{R x}+\mu_{R} \frac{d_{R}}{D_{R}} L_{R y}}+F_{B}+F_{S 1}+2 F_{S 2}+F_{n}+F_{P}-F_{C}$

* Technical contribution to the $2^{\text {nd }}$ International Brazilian Conference on Tribology - TriboBR 2014,November3' ${ }^{\text {rd }}$ to $5^{\text {th }}, 2014$, Foz do Iguaçu, PR, Brazil. 
Now, applying the sum of moments and equating to zero in the free-body diagram of Figure 4 at the specimen center and in relation to the $z$ axis, Equation (14) is obtained.

$-2 F_{R a} \frac{D_{B}}{2}+F_{f} \frac{d_{B}}{2}-F_{C} L_{C}+F_{S 1} L_{S 1}-2 F_{S 2} L_{S 2}+F_{n} L_{n}-F_{P} L_{P}=0$

Substituting Equation (10) into Equation (14) and solving to the frictional force $F_{f}$ Equation (15) is obtained.

$F_{f}=\frac{2}{d_{B}}\left(F_{R N} \mu_{R} \frac{d_{R}}{D_{R}} D_{B}+F_{c} L_{c}-F_{S 1} L_{S 1}+2 F_{S 2} L_{S 2}-F_{n} L_{n}+F_{P} L_{P}\right)$

Substituting the Equation (11) into the Equation (15) Equation (16) is obtained.

$F_{f}=f\left(F_{c}, F_{w}\right)=\frac{2}{d_{B}}\left[\frac{\mu_{R} d_{R} D_{B}\left(F_{w} L_{w}+F_{h} L_{R x}\right)}{2 D_{r}\left(L_{R x}+\mu_{R} \frac{d_{R}}{D_{R}} L_{R y}\right)}+F_{c} L_{c}-F_{S 1} L_{S 1}+2 F_{S 2} L_{S 2}-F_{n} L_{n}+F_{P} L_{P}\right]$

As weights were measured on a scale, it is necessary to use the relationships shown in Equation (17).

$$
\begin{aligned}
& F_{w}=m_{w} g \\
& F_{h}=m_{h} g \\
& F_{c}=m_{c} g \\
& F_{B}=m_{B} g \\
& F_{S 1}=m_{S 1} g \\
& F_{S 2}=m_{S 2} g \\
& F_{n}=m_{n} g \\
& F_{P}=m_{P} g
\end{aligned}
$$

Even as the set shown in Figure 4, the specimen and its accessories were heavy when assembled, so we made an option to consider $m_{B}^{*}$ as Equation (18).

$m_{B}^{*}=m_{B}+m_{s 1}+2 m_{s 2}+m_{n}+m_{p}$

Finally, substituting the Equations (17) and (18) into Equation (16) there is finally Equation (19) for the kinetic friction coefficient. This equation is a function of the mass of weights added to the rod load (dead weight system), and measurements in the load cell. It should be added that other constants are related to the apparatus geometry and the kinetic friction coefficient is not a function of the gravity acceleration.

$\mu=f\left(m_{c}, m_{w}\right)=\frac{\frac{2}{d_{B}}\left(\frac{\mu_{R} d_{R} D_{B}\left(m_{w} L_{w}+m_{h} L_{R x}\right)}{2 D_{R}\left(L_{R x}+\mu_{R} \mu_{R_{R}} L_{R y}\right)}+m_{c} L_{c}-m_{s 1} L_{s 1}+2 m_{s 2} L_{s 2}-m_{n} L_{n}+m_{P} L_{P}\right)}{\frac{m_{w} L_{w}+m_{h} L_{R x}}{L_{R x}+\mu_{R} R_{D_{R}} L_{R y}}-m_{c}+m_{B}^{*}}$

Furthermore, Equation (19) takes into account all forces identified in the free-body diagrams. However, it is assumed that some terms are not significant, such as those related to friction in bearings and moments generated by the weights of the screws,

* Technical contribution to the $2^{\text {nd }}$ International Brazilian Conference on Tribology - TriboBR 2014,November $3^{\text {rd }}$ to $5^{\text {th }}, 2014$, Foz do Iguaçu, PR, Brazil. 


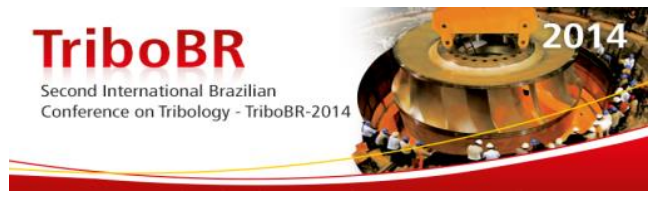

nut and plate. In order to perform that analysis, first it is necessary to determine the measurement uncertainty of the instruments used, which is essential for a correct analysis of the error propagation, and to obtain the standard uncertainty of the measurement apparatus.

\subsection{Standard Uncertainty of the Measuring Instruments}

For caliper and electronic scale, the influence of systematic calibration and environmental errors was considered. For calibration errors, the instrument accuracy was used as the error limit and the standard uncertainty for systematic errors were obtained by applying Equation (3). Data is presented in Table 2. Also, it was considered that the instruments had an arbitrary uncertainty of $0.05 \mathrm{~mm}$ and $0,05 \mathrm{~g}$, respectively. This consideration is necessary because both instruments were used in an environment that was not controlled, with variation in temperature and humidity. In order to obtain the standard uncertainty of the measuring instruments Equation (2) was used.

Table 2. Uncertainty of measuring instruments.

\begin{tabular}{ccc}
\hline Standard uncertainty & Vernier caliper $[\mathrm{mm}]$ & Electronic scale $[\mathrm{g}]$ \\
\hline Calibration & 0.025 & 0.005 \\
Environmental & 0.05 & 0.05 \\
\hline Total & 0.06 & 0.05 \\
\hline
\end{tabular}

Measurements were performed with the instruments described, which were necessary for evaluating the parameters in Equation (19). Data is shown in Table 3. Besides these, the mass of weights available for testing are given.

Table 3. Measurements of variables and masses weights.

\begin{tabular}{cc|cc}
\hline Parameter & Value & Parameter & Value \\
\hline$L_{c}$ & $31.30( \pm 0.06) \mathrm{mm}$ & $D_{R}$ & $32.00( \pm 0.06) \mathrm{mm}$ \\
$L_{R x}$ & $89.20( \pm 0.06) \mathrm{mm}$ & $m_{h}$ & $2442.15( \pm 0.05) \mathrm{g}$ \\
$L_{R y}$ & $15.25( \pm 0.06) \mathrm{mm}$ & $m_{s 1}$ & $2.02( \pm 0.05) \mathrm{g}$ \\
$L_{R Z}$ & $6.10( \pm 0.06) \mathrm{mm}$ & $m_{s 2}$ & $1.26( \pm 0.05) \mathrm{g}$ \\
$L_{w}$ & $228.50( \pm 0.06) \mathrm{mm}$ & $m_{n}$ & $0.52( \pm 0.05) \mathrm{g}$ \\
$L_{s 1}$ & $25.10( \pm 0.06) \mathrm{mm}$ & $m_{P}$ & $4.12( \pm 0.05) \mathrm{g}$ \\
$L_{s 2}$ & $16.10( \pm 0.06) \mathrm{mm}$ & Weight 1 & $701.23(( \pm 0.05) \mathrm{g}$ \\
$L_{n}$ & $16.60( \pm 0.06) \mathrm{mm}$ & Weight 2 & $1106.57(( \pm 0.05) \mathrm{g}$ \\
$L_{P}$ & $16.65( \pm 0.06) \mathrm{mm}$ & Weight 3 & $1284.14(( \pm 0.05) \mathrm{g}$ \\
$d_{B}$ & $20.10( \pm 0.06) \mathrm{mm}$ & Weight 4 & $2059.19(( \pm 0.05) \mathrm{g}$ \\
$D_{B}$ & $30.00( \pm 0.06) \mathrm{mm}$ & $m_{B}^{*}$ & $27.07(( \pm 0.05) \mathrm{g}$ \\
$d_{R}$ & $12.00( \pm 0.06) \mathrm{mm}$ & & \\
\hline
\end{tabular}

The load cell measurement uncertainty was carefully determined. The potential systematic and statistical errors were evaluated. There are not rare cases in which the evaluation is performed wrong, because often errors are dependent of variables that in a first analysis are disregarded. Also, the measurement uncertainty of an instrument throughout its usual range should be evaluated. If it was considered as a constant, it may be a mistaken assumption.

In the present case, the operating range of the apparatus is shown in Table 1. In this paper, it was chosen to evaluate a case study whose test conditions were presented

\footnotetext{
* Technical contribution to the $2^{\text {nd }}$ International Brazilian Conference on Tribology - TriboBR 2014,November $3^{\text {rd }}$ to $5^{\text {th }}, 2014$, Foz do Iguaçu, PR, Brazil.
} 


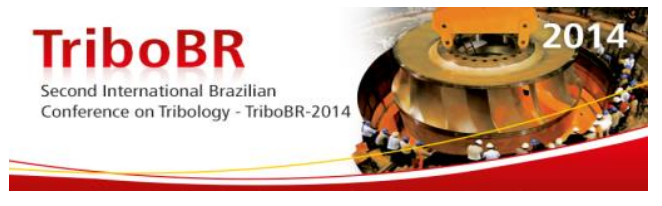

in reference [23]. Even so, values are resubmitted in Table 4. It can be checked that there was an increase of the applied load and a reduction of the shaft rotation, $n$.

Table 4. Test plan.

\begin{tabular}{ccccc}
\hline Variables & Condition 1 & Condition 2 & Condition 3 & Condition 4 \\
\hline $\mathrm{m}_{\mathrm{w}}[\mathrm{g}]$ & $701.23 \pm 0.05$ & $1807.80 \pm 0.07$ & $3091.94 \pm 0.09$ & $4044.56 \pm 0.09$ \\
$\mathrm{n}[\mathrm{rpm}]$ & 802.6 & 621.3 & 513.3 & 461.8 \\
\hline
\end{tabular}

For the load cell it was considered systematic and statistical errors. The first one was related to the calibration and the environment. The load cell error limit of calibration was considered equal to its accuracy that is $0.1 \mathrm{~g}$. Thus, applying Equation (3), the associated standard uncertainty of calibration, with a confidence level of $95.45 \%$ is $0.05 \mathrm{~g}$ for the entire range of the apparatus used. As the tests were performed in a not controlled atmosphere, a standard uncertainty of measurement for environmental systematic errors of $0.5 \mathrm{~g}$ was arbitrated.

The load cell statistical error, in its turn, is associated with the fluctuation of the measured value during the tests. However, in order to determine that error two conditions must be checked. First, the measurements must be taken when the system is stabilized. Thus, fluctuations are only associated with statistical errors and not to inherent phenomena that could be present during a long test. For the proposed case study, tests of PTFE sliding on stainless steel without lubrication were performed. The tribosystem reached stabilization after 100 min test. A detailed study about the determination of the stabilization time of the system can be found in reference [23]. Thus, measurements were taken for the evaluation after that period. Data collected between 115 and 120 minutes for each condition is shown in Figure 5.

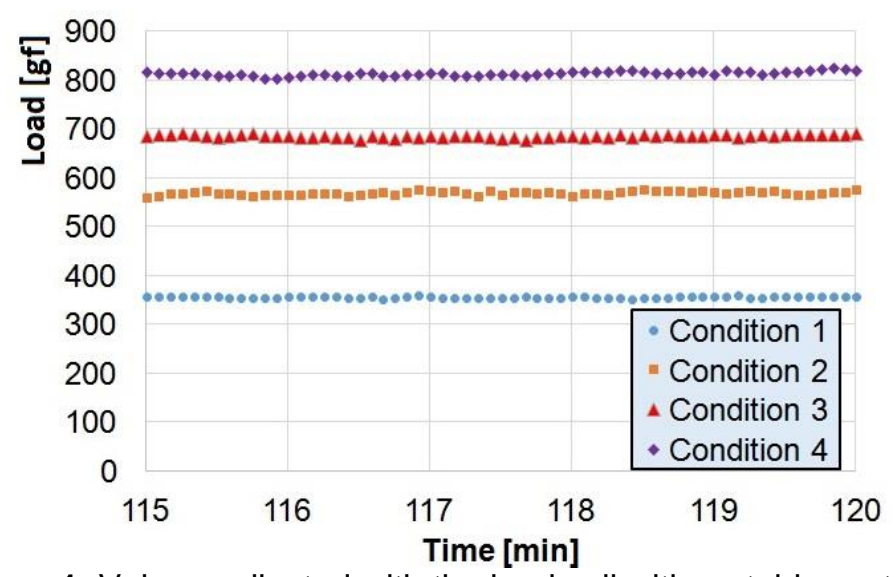

Figure 1. Values collected with the load cell with a stable system.

It is noted that the values collected are at different levels for each condition. This is due to the ratio of friction force to the normal force given in Equation (6). Moreover, is perceived that there were different levels of dispersion data for the tested conditions. There is a more stable situation for one condition and a larger fluctuation for the other ones. This can be explained, mainly, by an intrinsic condition of the apparatus, which showed different levels of vibration along the operation range.

The second condition that must be checked is whether the data collected is in agreement with a normal distribution. For that purpose, histograms of 50 measurements for each condition are presented in Figura 6. An error analysis on the

* Technical contribution to the $2^{\text {nd }}$ International Brazilian Conference on Tribology - TriboBR 2014,November $3^{\text {rd }}$ to $5^{\text {th }}, 2014$, Foz do Iguaçu, PR, Brazil. 


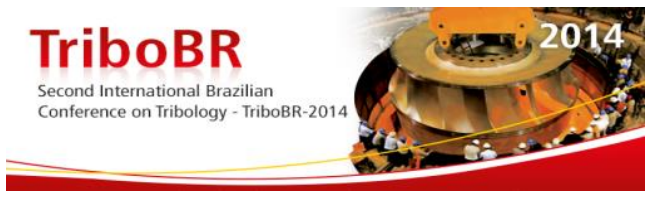

collected data is useful, in such cases, because it can provide better insight into the reliability of the collected data [24].

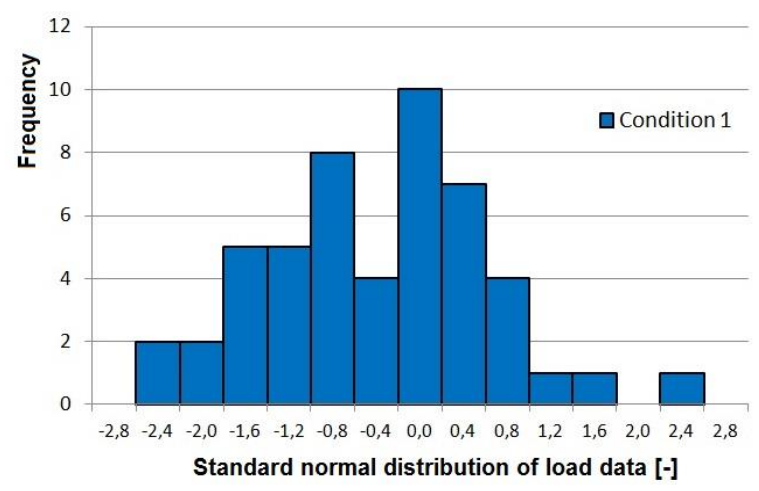

(a)

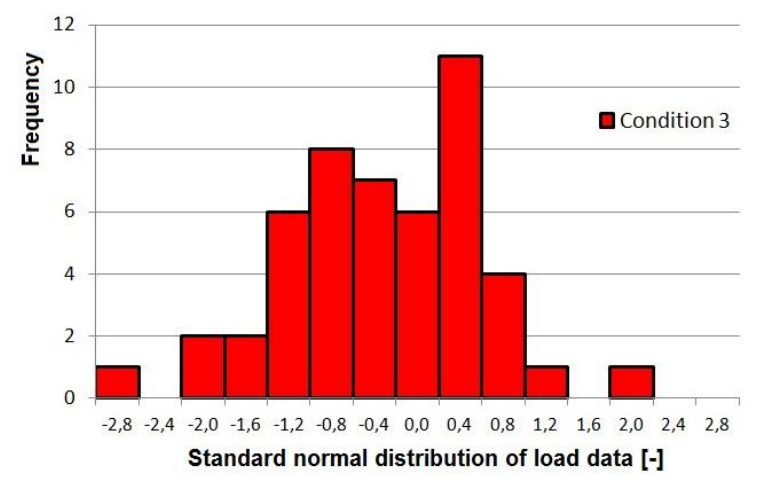

(c)

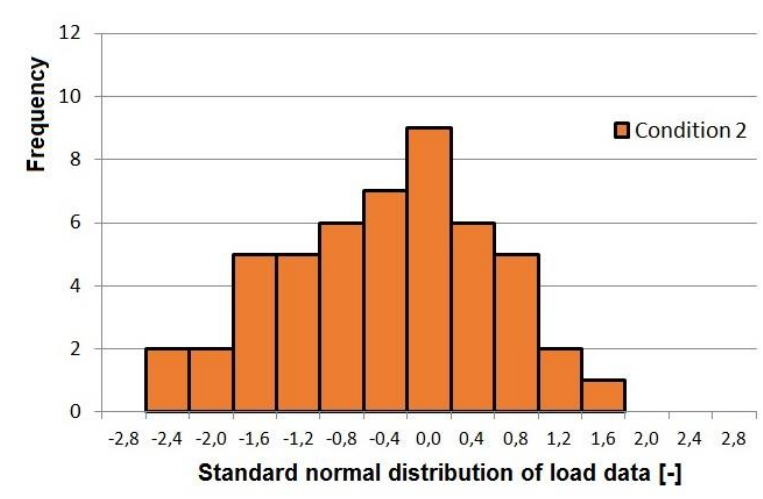

(b)

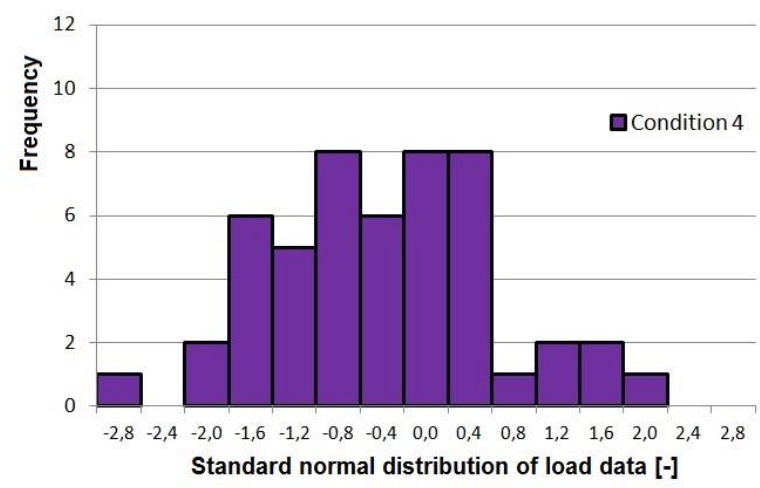

(d)

Figure 6. Histograms of load cell data collected with the system stabilized: (a) Condition 1 (b) Condition 2 (c) Condition 3 (d) Condition 4.

In order to evaluate whether data is in agreement with a normal distribution, the Shapiro-Wilk test was applied with a significance level of 0.05 on 50 data collected. The results for each condition are presented in Table 5 along with the critical value of a normal distribution with the same number of measurements. It might be noted that all values are greater than the value of a normal distribution. Thus, it can be concluded that the samples come from a population with a normal distribution with $95 \%$ of confidence.

Table 5. Shapiro-Wilk test

\begin{tabular}{|c|c|c|c|c|}
\hline Variables & Condition 1 & Condition 2 & Condition 3 & Condition 4 \\
\hline$W_{\text {calc }}$ & 0.981 & 0.971 & 0.974 & 0.992 \\
\hline $\mathrm{W}_{(0.05 ; 50)}$ & \multicolumn{4}{|c|}{0.947} \\
\hline
\end{tabular}

With both verifications performed, the statistical error limit can be determined with Equation (4) and the measurement uncertainty associated with the statistical errors, with a confidence level of $95.45 \%$, with Equation (3). A summary of the values is shown in Table 6 . In order to calculate the uncertainty of the systematic error, and the total standard uncertainty of the load cell Equation (2) and (1) were respectively applied.

\footnotetext{
* Technical contribution to the $2^{\text {nd }}$ International Brazilian Conference on Tribology - TriboBR 2014,November3 ${ }^{\text {rd }}$ to $5^{\text {th }}, 2014$, Foz do Iguaçu, PR, Brazil.
} 


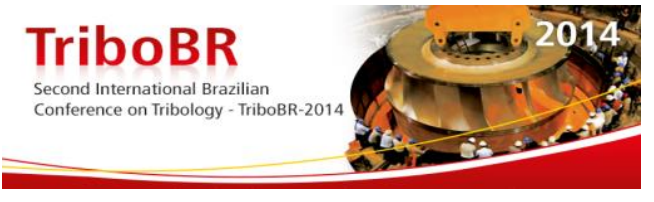

Table 6. Cell load standard uncertainty.

\begin{tabular}{cccccc}
\hline Standard uncertainty & Condition 1 & Condition 2 & Condition 3 & Condition 4 \\
\hline Statistical [gf] & 2.1 & 3.70 & 3.78 & 5.68 \\
Calibration [gf] & & & 0.05 & & \\
Environmental [gf] & & & 0.5 & & \\
\hline Total [gf] & 2.2 & 3.7 & & 3.8 & 5.7 \\
\hline
\end{tabular}

With an analysis of Table 6 it can be verified that the statistical uncertainty dominated the standard uncertainty behavior of the measurement apparatus. The variation presented throughout the apparatus operation range emphasizes the relevance of such evaluation. The values of standard deviations and standard errors to the statistical uncertainty are presented in Figure 7 . It can be observed that the values of standard deviations are always smaller than the standard error of the statistical uncertainty. This can be explained by the formulation the two quantities. All values are taken into consideration to determine the standard deviation, and so that parameter has low sensitivity to eventual peaks. However, the measurement uncertainty takes into account only the greatest difference between the measured values and its mean. With that, it can be concluded that there were higher peaks for the conditions 3 and 4 .

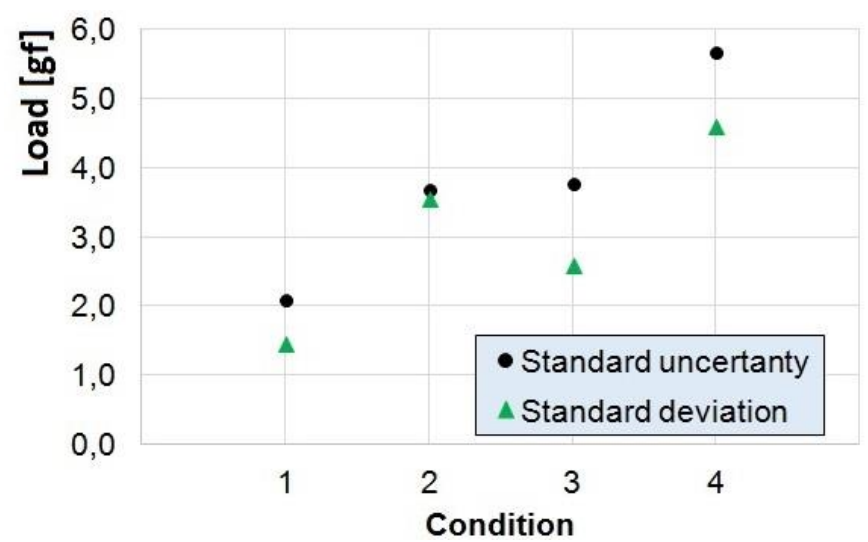

Figure 7. Comparison between the statistical standard uncertainty and the standard deviation of the cell load.

\subsection{Statistical Significance Analysis}

After obtaining the measuring instruments uncertainties and the parameters needed in Equation (19), it is possible to evaluate the statistical significance of certain terms, which seem to be not significant. The first term evaluated was $\boldsymbol{\theta}_{\mathbf{1}}$, which is shown in Equation (20). This term appears twice, in the numerator and the denominator of Equation (19), added to $L_{R x}$.

$\theta_{1}=\mu_{R} \frac{d_{R}}{D_{R}} L_{R y}$

The $\theta_{1}$ value can be calculated with the information from Table 3 and its standard uncertainty by doing an analysis of error propagation through applying the Equation (5). With that, $\theta_{1}=0.00858( \pm 0.00006) \mathrm{mm}$ was obtained. It might be observed that the value obtained is one magnitude below the standard measurement uncertainty of $L_{R x}$. Thus, it was assumed that this term has no significance and can be simplified in Equation (19).

* Technical contribution to the $2^{\text {nd }}$ International Brazilian Conference on Tribology - TriboBR 2014,November $3^{\text {rd }}$ to $5^{\text {th }}, 2014$, Foz do Iguaçu, PR, Brazil. 
In order to evaluate the numerator of Equation (19) the terms $\theta_{2}, \theta_{3}$ and $\theta_{4}$ are presented in Equations (21), (22) and (23), respectively. It is observed that the term $\theta_{4}$ is constant and depends on the moments caused by the specimen and its accessories. The terms $\theta_{2}$ and $\theta_{3}$, on the other hand, are dependent on the weights added to the rod load, $m_{w}$, and the values measured on the load cell, $m_{c}$, respectively. With this, both terms present variation along the operating range of the apparatus.

$$
\begin{aligned}
& \theta_{2}=f\left(m_{w}\right)=\frac{\mu_{R} d_{R} D_{B}\left(m_{w} L_{w}+m_{h} L_{R x}\right)}{2 D_{R} L_{R x}} \\
& \theta_{3}=f\left(m_{c}\right)=m_{c} L_{c} \\
& \theta_{4}=-m_{S 1} L_{S 1}+2 m_{S 2} . L_{S 2}-m_{n} L_{n}+m_{P} L_{P}
\end{aligned}
$$

The $\theta_{2}$ values were calculated for each test condition presented in Table 4 . The $\theta_{3}$ values were calculated using the mean of 50 values collected in each condition and already presented in Figure 5. Both results are shown in Table 7.

Table 7. Evaluation of $\boldsymbol{\theta}_{2}, \boldsymbol{\theta}_{3}$ and $\boldsymbol{\theta}_{4}$.

\begin{tabular}{cccccc}
\hline Condition & $\theta_{2}[\mathrm{gf} . \mathrm{mm}]$ & $m_{c}[\mathrm{gf}]$ & $\theta_{3}[\mathrm{gf} . \mathrm{mm}]$ & $\theta_{4}$ [gf.mm] & $\sigma_{\theta_{3}}$ [gf.mm] \\
\hline 01 & $35.69( \pm 0.15)$ & $357.4( \pm 2.2)$ & $11187( \pm 71)$ & & 93.8 \\
02 & $59.51( \pm 0.25)$ & $577.7( \pm 3.7)$ & $18082( \pm 122)$ & $49.83( \pm 2.4)$ & 144.6 \\
03 & $87.13( \pm 0.40)$ & $694.3( \pm 3.8)$ & $21732( \pm 126)$ & & 161.1 \\
04 & $107.63( \pm 0.51)$ & $828.4( \pm 5.7)$ & $25929( \pm 185)$ & & 219.8 \\
\hline
\end{tabular}

As shown in Equation (19), the terms $\theta_{2}$ e $\theta_{4}$ are added to $\theta_{3}$ and its values have the same magnitude order of the $\theta_{3}$ measurement standard uncertainty. Thereby, it was decided to simplify them from the Equation (19), but consider them as a systematic error for $\theta_{3}$. Thus, the new standard uncertainty of $\theta_{3}, \sigma_{\theta_{3}}$ was determined by applying Equation (2), which is presented in Table 7. As explained, it is possible to simplify the terms described in Equation (19), and present the Equation (24), which was used to determine the kinetic friction coefficient.

$$
\mu=f\left(m_{c}, m_{w}\right)=\frac{2}{d_{B}}\left(\frac{m_{c} L_{c}}{\frac{L_{w}}{L_{R x}} m_{w}+m_{h}-m_{c}+m_{B}^{*}}\right)
$$

\subsection{Standard Uncertainty of the Apparatus}

After the deduction of Equation (24), which is used to determine the kinetic friction coefficient, it is still necessary to obtain the measurement standard uncertainty for this variable. For this task is accomplished through an error analysis propagation, by applying Equation (5) in Equation (24). Also, the information from the proposed case study needs to be taken into account. The results of this analysis are presented in Table 8. It might be noted that, despite the standard uncertainties associated to the load cell presenting distinct values, the measurement apparatus standard uncertainties were 0.002 for all four test conditions proposed.

\footnotetext{
* Technical contribution to the $2^{\text {nd }}$ International Brazilian Conference on Tribology - TriboBR 2014,November $3^{\text {rd }}$ to $5^{\text {th }}, 2014$, Foz do Iguaçu, PR, Brazil.
} 


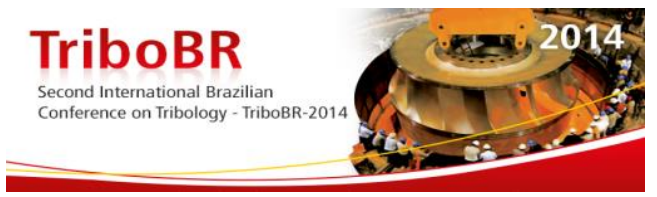

b) For the load cell, systematic and statistical errors were considered. The first one was related to calibration and environmental errors. Statistical errors were studied over the operating range of the apparatus. A test plan was used for an evaluation of four conditions;

c) Two considerations were satisfied to the load cell data in order to calculate its standard uncertainty. First, the data was collected on a steady-state condition of the tribosystem. Second, applying a Shapiro-Wilk inference test was verified that the samples data came from a normal distribution;

d) The standard uncertainty of the cell load showed variation, over the operating range of apparatus, and values from 2.2 to $5.7 \mathrm{~g}$. The Statistical errors were dominant in these values;

e) After an evaluation of the statistical significance of three terms in the kinetic friction coefficient equation, one of them was simplified, because its value was smaller than the standard uncertainty of term added to it. The values of the other two terms had the same magnitude of the standard uncertainty of term added to them. So, both terms were simplified and considered as a systematic error;

f) The measurement standard uncertainties for the kinetic friction coefficient were determined, and their values were 0.002 to all four conditions;

g) Despite the standard uncertainty of the load cell displaying a large variation along the operating range of the apparatus, the standard uncertainties of kinetic friction coefficient were practically the same.

\section{Acknowledgments}

The authors would like to express their sincere gratitude to the support from PPGEM (Post-Graduated Program of Mechanical and Materials Engineering) Mechanical Engineering Department (DAMEC/UTFPR). Additionally, our special thanks to CNPq for providing a scholarship (134598/2013-0).

\section{REFERENCES}

1 Khoddamzadeh A, Liu R, Wu X. Novel Polytetrafluoroethylene (PTFE) Composites with Newly Developed Tribaloy Alloy Additive for Sliding Bearing. Wear, 2009; 266: 646-657. Conte M, Igartua A. Study of PTFE composites tribological behavior. Wear, 2012; 296: 568-574.

3 Liu XX, Li TS, Liu XJ, Lv RG, Cong PH. An investigation on the friction of oriented polytetrafluoroethylene (PTFE). Wear, 2007; 262: 1414-1418.

4 Kim SS, Shin MW, Jang $H$. The Wear Mechanism of a Polyphenylene Sulfide (PPS) Composite Mixed with Ethylene Butyl Acrylate (EBA). Tribology Letters, 2012; 47: 165173.

5 Koike H, Kida K, Santos EC, Rozwadowska J, Kashima Y, Kanemasu K. Selflubrication of PEEK polymer bearings in rolling contact fatigue under radial loads. Tribology International, 2012; 49: 30-38.

6 Liu Y, Schaefer JA. The Sliding Friction of Thermoplastic Polymer Composites Tested at Low Speeds. Wear, 2006; 261: 568-577.

7 Marx S, Junghans R. Friction and Wear of Highly Stressed Thermoplastic Bearing Under Dry Sliding Conditions. Wear, 1996; 193: 253-260.

8 Dai L, Satyanarayana N, Sinha S, Tan VBC. Analysis of PTFE lubricating film in NEMS application via molecular dynamics simulation. Tribology International, 2013; 60: 53-57.

9 Kashani MR, Behazin E, Fakhar A. Construction and evaluation of a new tribometer for polymers. Polymer Testing, 2011; 30: 271-276.

* Technical contribution to the $2^{\text {nd }}$ International Brazilian Conference on Tribology - TriboBR 2014,November $3^{\text {rd }}$ to $5^{\text {th }}, 2014$, Foz do Iguaçu, PR, Brazil. 


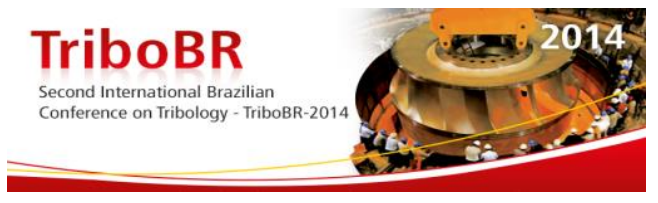

10 Allmaier H, Priestner C, Six C, Priebsch HH, Forstner C, Forstner F. Predicting friction reliably and accurately in journal bearings - A systematic validation of simulation results with experimental measurements. Tribology International, 2011; 44: 1151-1160.

11 Lu X, Khonsari MM. On the lift-off speed in journal bearings. Tribology Letters, 2005; 20: 299-305.

12 Lu X, Khonsari MM. An Experimental Investigation of Dimple Effect on the Stribeck Curve of Journal Bearings. Tribology Letters, 2007; 27: 169-176.

13 Adatepe $H$, Bıyıklıglu A, Sofuoglu $H$. An experimental investigation on frictional behavior of statically loaded micro-grooved journal bearing. Tribology International, 2011; 44: 1942-1948.

14 Ünlü BS, Durmus H. Determination of tribological properties at CuSn10 alloy journal bearings by experimental and means of artificial neural networks method. Industrial Lubrication and Tribology, 2012; 64: 258-264.

15 Ünlü, B.S. Tribological and mechanical properties of PM journal bearings. Powder Metallurgy, Vol. 54, p. 338-342, 2011.

16 Ünlü BS, Atik E. Determination of friction coefficient in journal bearings. Materials and Design, 2007; 28: 973-977.

17 ASM Handbook Volume 18 - Friction, Lubrication and Wear Technology. USA: 1992.

18 Budinsky KG.; Bayer, R.G. Friction in machine design. Tribological Modeling for Mechanical Designers. ASTM STP 1105, American Society for Testing and Materials, 1991: 89-126.

19 Taylor JR. Introduction to Error Analysis: The Study of Uncertainties in Physical Measurements. 2nd ed., Calif.: University Science Books, 1997.

20 Drosg M. Dealing with Uncertainties: A Guide to Error Analysis. 2nd ed, Springer Berlin Heidelberg, 2009.

21 Shapiro SS, Wilk MB. An analysis of variance for normality (complete samples). Biometrika, 1965; 52: 591-611.

22 SKF. SKF spherical roller bearings: Setting the standard for performance and reliability, Sweden, 2007.

23 Vale JL. Estudo do comportamento tribológico do politetrafluoretileno em deslizamento sem lubrificação contra aço inoxidável,165p., Master's Thesis, Federal University of Technology - Paraná (UTFPR), Curitiba, 2014. Available: http://www. utfpr.edu.br/curitiba/estrutura-universitaria/diretorias/dirppg/ programas/ppgem/bancoteses/dissertacoes/2014/VALEJoaoLuiz.pdf [Accessed 25 August 2014].

24 Qajar A, Peer M, Rajagopalan R, Foley HC. High pressure hydrogen adsorption apparatus: Design and error analysis. International journal of hydrogen energy, 2012; 37: 9123- 9136.

* Technical contribution to the $2^{\text {nd }}$ International Brazilian Conference on Tribology - TriboBR 2014,November3' ${ }^{\text {rd }}$ to $5^{\text {th }}, 2014$, Foz do Iguaçu, PR, Brazil. 